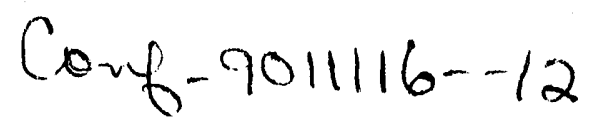

\title{
DISCLAIMER
}

This report was prepared as an account of work sponsored by an agency of the United States Government. Neither the United States Government nor any agency thereof, nor any of their employees, makes any warranty, express or implied, or assurnes any legal liability or responsibility for the accuracy, completeness, or usefulness of any information, apparatus, product, or process disclosed, or represents that its use would not infringe privately owned rights. Reference herein to any specific commercial product, process, or service by trade name, trademark, manufacturer, or otherwise does not necessarily constitute or imply its endorsement, recommendation, or favoring by the United States Government or any agency thereof. The views and opinions of authors expressed herein do not necessarily state or reflect those of the United States Government or any agency thereof.

WSRC-RP- $-90-1122$

DE92 010037

\section{TECHNICAL BASES FOR THE DWPF TESTING PROGRAM (U)}

by

\section{J. Plodinec}

Westinghouse Savannah River Company

Savannah River Site

Aiken, South Carolina 29808

A paper proposed for presentation at the

Scientific Bases for Nuclear Waste Management

Boston, Massachusetts

November 26, 1990

and for publication in the proceedings

This paper was prepared in connection with work done under Contract No. DE-ACO9-89SR18035 with the U.S. Department of Energy. By acceptance of this paper, the publisher and/or recipient acknowledges the U.S. Government's right to retain a nonexclusive, royalty-free license in and to any copyright covering this paper, along with the right to reproduce and to authorize others to reproduce all or part of the copyrighted paper. 
Keywords: DWPF, glass, leaching

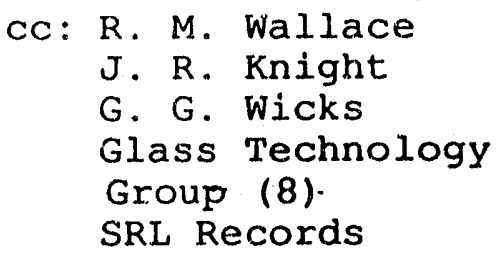

Retention time: 5 years

September 17, 1990

To: J. R. Knight

From: M. J. Plodinec 


\title{
TECHNICAL BASES FOR THE DWPF TESTING PROGRAM
}

\author{
M.J. Plodinec \\ Westinghouse Savannah River Company \\ Savannah River Laboratory \\ Post Office Box 616 \\ Aiken, South Carolina 29802
}

\begin{abstract}
The Defense Waste Processing Facility (DWPF) at the Savannah River Site (SRS) will be the first production facility in the United States for the immobilization of high-level nuclear waste. Production of DWPF canistered wasteforms will begin prior to repository licensing, so decisions on facility startup will have to be made before the final decisions on repository design are made. The Department of Energy's Office of Civilian Radioactive Waste Management (RW) has addressed this discrepancy by defining a Waste Acceptance Process. This process provides assurance that the borosilicate-glass wasteform, in a stainless-steel canister, produced by the DWPF will be acceptable for permanent storage in a federal repository. As part of this process, detailed technical specifications have been developed for the DWPF product.
\end{abstract}

SRS has developed detailed strategies for demonstrating compliance with each of the Waste Acceptance Process specifications. An important part of the compliance is the testing which will be carried out in the DWPF. In this paper, the bases for each of the tests to be performed in the DWPF to establish compliance with the specifications are described, and the tests are detailed. The results of initial tests relating to characterization of sealed canisters are reported.

\section{INTRODUCTION}

The 130 million liters of high-level ruclear waste (HLW) from the production of nuclear materials at the Savannah River Site (SRS) are currently stored as alkaline slurries in carbon steel tanks. While this mode of disposal has been safe and effective, it requires continuous monitoring, and is clearly only a temporary expedient. Construction of the Defense Waste Processing Facility (DWPF) at SRS began in 1983, to immobilize the HLW from production reactors at SRS into a durable borosilicate glass wasteform, thus to produce a wasteform suitable for permanent disposal. The DWPF at SRS is the first facility in the United States designed for the routine production of high-level nuclear wasteforms. This facility will serve as the model for later defense HLW processing efforts, e.g., at the Hanford Site.

Pre-operational testing of the DWPF has now begun. Conceptual design activities for the nation's first repository will not begin until after virtually all of the DWPF testing is completed. Thus, decisions on whether the DWPF is ready to begin actual radioactive operations will have to be made before decisions on repository design are finalized. The Department of Energy's Office of Civilian Radioactive Waste Management (RW) has addressed this discrepancy by defining a Waste Acceptance Process to provide assurance that the wasteforms produced in the DWPF will be acceptable for permanent storage in a federal repository. As part of this process, detailed technical specifications have been developed for the DWPF product by RW. 
The Waste Acceptance Preliminary Specifications (WAPS) define the requirements and testing for the following:

- the chemical composition, radionuclide inventory, control of durability, and thermal stability of the borosilicate glass

- the material, label, and closure of the wasteform canister

- the dimensions and weight, surface contamination, foreign materials, heat generation and dose rate, criticality, handling features, and ability to survive a drop of the final wasteform provluct.

In addition to these requirements on its product, the DWPF must also: 1) comply with environmental regulations; 2) protect the health and safety of its workers; and 3) immobilize the liquid HLW in a timely manner.

In order to provide assurance that all of these requirements will be met prior to facility startup, a comprehensive and diciplined DWPF Startup Test Program has been established, modeled on the testing required for the startup of a commercial reactor. The conventional systems approach used for startup of nuclear reactor has been modified to take into account the unique nature of the facility, the new technologies employed, and the wide diversity of technologies which must be integrated. However, the thoroughness of planning and attention to disciplined operations of a commercial nuclear facility has been maintained.

The DWPF Startup Test Program objectives ars:

- verification that the individual systems perform as clesigned,

- demonstration that the integrated DWPF process gind product controls are adequate to satisfy the requirements of the WAPS.

In addition, the testing provides the opportunity to collect baseline data on equipment operation which will be of use in diagnosing problems encountered during actual operations. All of the tests which will be performed are listed in Table 1. Each of the tests in the Table which are primarily for Waste Acceptance purposes are identified by a "WP" in the test number. The testing which addresses the WAPS' requirements is stressed in the following sections.

\section{DEFENSE WASTE PROCESS FACILITY PROCESS}

In order to better understand the Test Program, it is necessary to understand the DWPF processs. This has been described in detail by several authors, [1-3] and thus is only summarized here. A diagram of the entire immobilization pracess is shown in Figure 1.

SRS HLW is currently stored at SRS as a mixture of insoluble sludges (primarily metal hydroxides of iron, aluminum, and manganese) and soluble salts (Largely sodium nitrate, sodium nitrite, sodium alumininate, and sodium hydroxide). Both the sludge and the salt are treated in the waste tanks to concentrate the radionuclides, and thereby reduce the volume of material to be vitrified in the DWPF. The sludge is washed with water to remove non-radioactive soluble salts. Sludges high in aluminum are treated with hot caustic and then washed to remove aluminum. The salt fraction is treated with sodium tetraphenylborate to precipitate radioactive cesium, and with sodium titanate to sorb the 


\section{EIGURE 1}

IMMOB ILIZATION OE SRP HIGH-LEVEL BADIOACTIVE WASTE

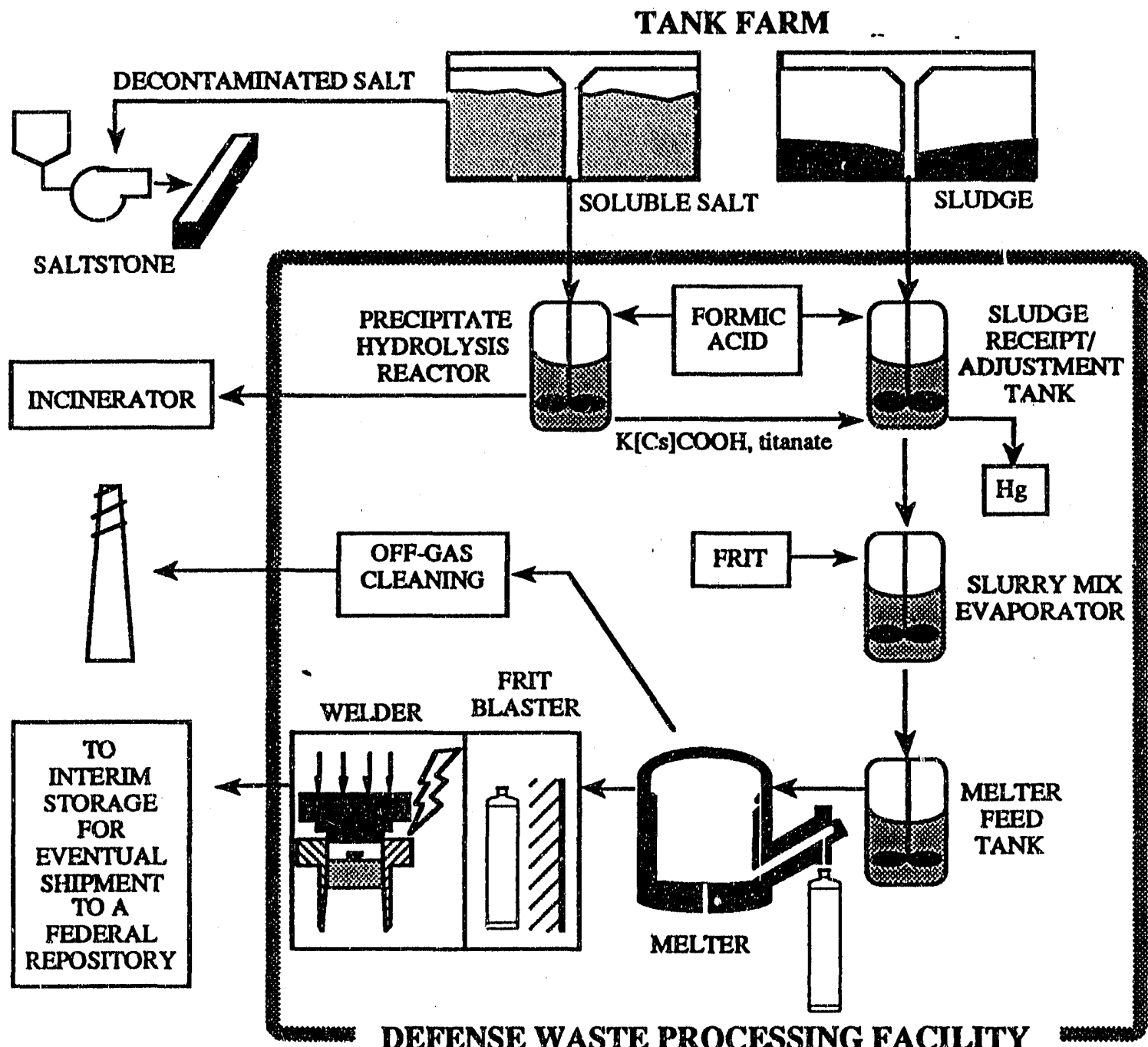


traces of radioactive strontium and plutonium in the soluble waste. The solid materials which contain virtually all of the radioactivity from the soluble fraction are then washed in the waste tanks prior to delivery to the DWPF.

Within the vitrification building, about $90 \%$ of the organic content of the tetraphenylborate salt is removed by hydrolysis with formic acid (precipitate hydrolysis). This is necessary to avoid overly reducing conditions in the melter and off-gas systems. The aqueous product, which contains the cesium, boron, and the insoluble titanate with sorbed strontium and plutonium, is then fed to the Sludge Receipt and Adjustment Tank (SRAT).

The washed sludge slurry and the precipitate hydrolysis product are mixed together in the SRAT. The slurry is then transferred to the Slurry Mix Evaporator (SME) where premelted borosilicate glass frit is added. The resulting mixture is then transferred to the Melter Feed Tank (MFT), which delivers feed to the melter. Thus, the feed to the melter is composed of three components: frit, sludge, and precipitate hydrolysis produce, in the proportions 64:28:8 on a weight percent oxide basis.

Vitrification is accomplished in a slurry-fed, Joule-heated melter. The feed slurry is introduced from the top of the melter and forms a crust, or cold cap, on the surface of the melt pool as the water is evaporated and removed via the off-gas system. The cold cap melts from the bottom and forms the borosilicate waste glass matrix. The nominal glass temperature beneath the cold cap is $1150^{\circ} \mathrm{C}$. but varies throughout the melter.

Glass is removed from near the bottom of the DWPF melter through a riser and pour spout connected to a stainless steel canister. Pouring is accomplished by drawing a vacuum on the pour spout relative to the melter. After a canister is filled, it is decontaminated by air-injected frit slurry blasting, welded closed, and taken to interim storage at the SRS, until a federal repository is available.

\section{TEST PROGRAM}

The sections below describe specific tests which will be performed during the DWPF Startup 'Tes! Program to satisfy the WAPS. In addition, most of the routine operations and procedures which will be performed during actual production and routinely reported to the jepository will also be performed during this time. A complete listing of the tests included in the Startup Test Program is given in Table 1.

\section{Glass Melting Campaigns}

The most important activities at this time, in terms of the Waste Acceptance Process, are the campaigns with synthetic waste materials, by which integrated operation of the entire facility will be demonstrated.[4] The objective of these campaigns is to show that the DWPF can produce an acceptable product over a range of material properties which represent the most adverse conditions that the vitrification system is likely to see. This range has been defined based on sampling of waste from the waste tanks and estimates of future waste generation at the SRS. The glass compositions include: 1) the glass composition projected to be produced initially; 2 ) an extreme composition high in aluminum based on a particular nuclear materials flowsheet used at the SRS; 3) another extreme composition which represents a worst-case composition for the DWPF; and 4) the designbasis composition for the facility. 
Tests in Bold will produce data relevant to Waste Acceptance

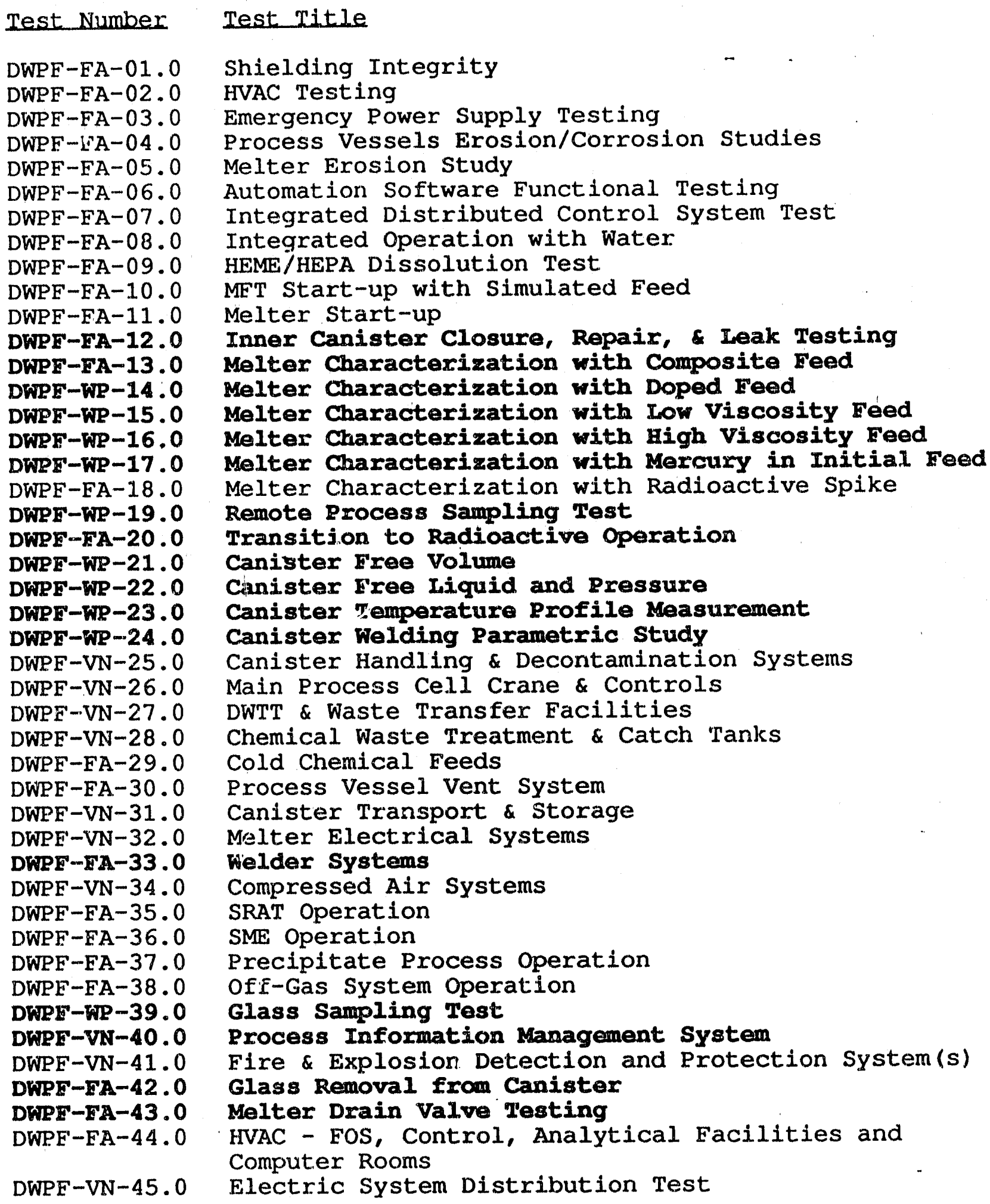


Since the waste fed to the DWPF will vary in composition, the DWPF product control scheme has been designed to tolerate this variability and still produce a product which meets specifications. The DWPF will control the glass product by controlling the feed composition in the last feed preparation vessel, the SME. The free energy of hydration model developed by SRL [5-7] will be used to set a target composition for a given batch of feed in the tank farm. This model will also determine whether batches of feed will make acceptable glass, and to guide adjustments if necessary.

Definition of target composition - before a batch of waste is processed in the DWPF, the free-energy model will be used to establish a target glass composition which will meet the specification. This composition vill be defined so that the free energy of hydration of the target will ensure that the target glass will meet the durability criterion. At the same time, a sampling regimen (number of samples, number of analyses per sample) for each batch will be specified so the DWPF production staff can be assured that the confidence limit of the specification will be met for each batch. Thus, this specification of the sampling regimen will include consideration of the errors of samplirig and analyses, as well as the uncertainty in the correlation between the free energy of hydration and the leach test results. A nuajor objective of the DWPF Startup Test Program will be to quantify these errors.

Determination of acceptability - samples of each batch of feed from the last feed preparation vessel (SME on Figure 1) will be taken. The number of samples will be based on the number of measuremnts necessary to provide at least $95 \%$ confidence that $95 \%$ of the product would meet the product durability criterion. The chemical composition and the $\mathrm{FE}$ (II)/Fe(III) ratio measured on a vitrified sample of feed will be used to calculate the free energy of hydration. If the calculated free energy indicates that the feed will make acceptable glass, the feed will be transferred to the Melter Feed Tank, and then on to the melter.

Feed adjustment - if the free energy calculated appears to be unacceptable, the feed will be adjusted to bring it into acceptability. In general, addition of frit will be all that is necessary. Transfer of material to the Melter Feed Tank will only be allowed when it has been determined that the SME material is within the operating limit.

The tests indentified in the DWPF Startup Test Program for wasteform compliance are based on the thesis that the most likely way in which the process control scheme will fail is through segregation of the feed material. Thus, the rheology of the feed slurries and the glass will be varied over a wide range of values, much more rapidly than expected, as an "overtest" of the ability to maintain control of the product even under adverse processing conditions.

The initial charge to the melter will be a glass frit specially formulated for melter startup. After building the melter level to the operating level, a series of test runs will be made to analyze the feed systern and melter behavior. These tests will use simulated sludge and precipitate of the following compositions.

- A composite feed to purge the startup frit from the melter and establish a base condition ( 24 canisters produced, corresponding to 6 melter turnovers),

- a nonradioactive doped composition to simulate variations around the composite feed ( 20 canisters produced, corresponding to 5 melter turnovers),

- a high viscosity (high aluminum) composition to simulate an extreme change in feed composition ( 20 canisters produced, corresponding to 5 melter turnovers), 
- a low viscosity (high iron) compositon to simulate another extreme change in feed composition (20 canisters produced, corresponding to 5 melter turnovers), and

- a composite feed to simulate return to standard operation from low viscosity (20 canisters produced, corresponding to 5 melter turnovers)

In addition, another run with a radioactive dopant will be performed to demonstrate decontamination of gaseous effluents.

At least one of these runs will require the addition of supplemental chemicals to demonstrate that the feed composition can be adjusted, if required. Approximately 75,000 pounds of glass will be made during each of these tests to provide about a $95 \%$ changeover of melter composition, assuming that the melter behaves like a well-stirred tank.

Since chemical composition is the most important determinant of glass durability, analysis and testing (using the DWPF Product Consistency Test (PCT) ] $[8,9]$ of glass "grab" samples from each canister produced will be used to demonstrate that the approach to meeting the WAPS has been successful. The canisters produced during the Test Program will also be sectioned, and the sections sampled. Any crystalline phases present will be identified and their content determined, and the behavior of samples takena with the DWPF glass sampler compared to samples of glass taken from the sectioned canisters.

\section{Other Waste Acceptance Tests}

Chemical and Phase Stability - cooldown profiles obtained fom canisters produced during pilot-scale testing will be verified under typical production conditions in the DWPF. In addition, the effect of placing a canister in the Melt Cell Insulated Storage Rack on the thermal profile will be evaluated. Special instrumented canisters are being designed and procured to perform these tests.

Fabrication and Closure - previous parametric weld studies performed at the SRS [10] will be confirmed using the DWPF welder. Initial runs will be made on dummy heads, and will span the entire range of operating conditions. Then full-scale canisters will be used to demonstrate actual operation. The quality of the welds produced will be verified by metallurgical characterization, and physical testing.

Foreign Materials - tests will be performed to confirm that the Inner Canister Closure [11] prevents the intrusion of water, when installed under typical operating conditions, particularly from the canister decontamination operation. Tests will also be performed to demonstrate that canistered wasteforms will not contain prohibited gases, and will be below 7 psig after cooling. A special canister penetration system has been designc and tested which allows the vapor space in the top of sealed canisters to be sampled. The pressure inside the canister can be measured, the relative humidity and dewpoint of the vapor inside the canister can be determined, and the vapor can be sent to a mass spectrometer for gas analysis.

The system has been tested with four canisters produced from pilot-scale testing.

- all four canisters tested were at less than atmospheric pressure, indicating that the temporary seal had maintained a slight vacuum for at least two years.

- dewpoints ranged from $-10^{\circ} \mathrm{C}$ to $+6^{\circ} \mathrm{C}$, while relative humidities were in the range from $5 \%$ to $20 \%$. 
- for three of the canisters, the $\mathrm{N}_{2} \mathrm{CO}_{2}$ ratio was approximately that of air. For the fourth the ratio indicated that the canister was actually depleted in $\mathrm{CO}_{2}$, by about a factor of fifty. The glass in this canister will be examined to try to determine the fate of the $\mathrm{CO}_{2}$. This system will be used on several of the canisters produced during the Test Program

Eree Yolume - Confirmation of an operable, level-detection system is required to demonstrate control of the free volume in the canister (desired minimum fill is $80 \%$ ). The DWPF will demonstrate the neutron transmission method for canister level determination during the Integrated Cold Runs.

\section{REFERENCES}

1. M.D. Boersma, American Nuclear Society - Fuel Reprocessing and Waste Management, 1,131-47 (1984)

2. A.F. Weisman, L.M. Papouchado, J.R. Knight, and D.L. Mclntosh, Waste Management 88, 2, Roy G. Post (ed.), 203-10 (1988)

3. D.L. McIntosh and L.M. Papouchade, High-Level Radioactive Waste Management, Proceedings of the International Topical Meetine, D.B. Shipler (ed.), USSDOE, Washington, DC, 794-801 (1990)

4. J.A. Gentilucci, Waste Management 89, 1,Roy G. Post (ed.), 723-8 (1989)

5. M.J. Plodinec, C.M. Jantsen, and G.G. Wicks, Advances in Ceramics Nuclear Waste Management, 8, W.A. Ross and G.G. Wicks (eds.), 491-95 (1984)

6. C.M. Jantsen and M.J. Plodinec, J. Non-Cryst. Solids, 67, 207-23 (1984)

7. J.T. Carter, K.G. Brown, and D.F. Bickford, Proceedings - First International Conference on Advances in the Fusion of Glass, D.F. Bickford, etal. (ed.), American Ceramic Society, Westerville, $\mathbf{O H}$, Chapter 20 (1988)

8. N.E. Bibler and C.M. Jantsen, Waste Management 89, 1, Roy G. Post (ed.), 743-9 (1989)

9. N.E. Bibler, and J.K. Bates, Scientific Basis for Nuclear Waste Management, XIII, V.M. Oversby (ed.), Materials Research Society, Pittsburgh, PA, 327-38 (1990)

10. B.J. Eberhard, and J.W. Kelker, Welding Journal, 62, 662-3 (1982)

11. J.W. Kelker, Development of the DWPF Canister Temporary Shrink-Fit Seal, USDOE Report DP-1720, Savannah River Laboratory, Aiken, SC 29802 (1986) 

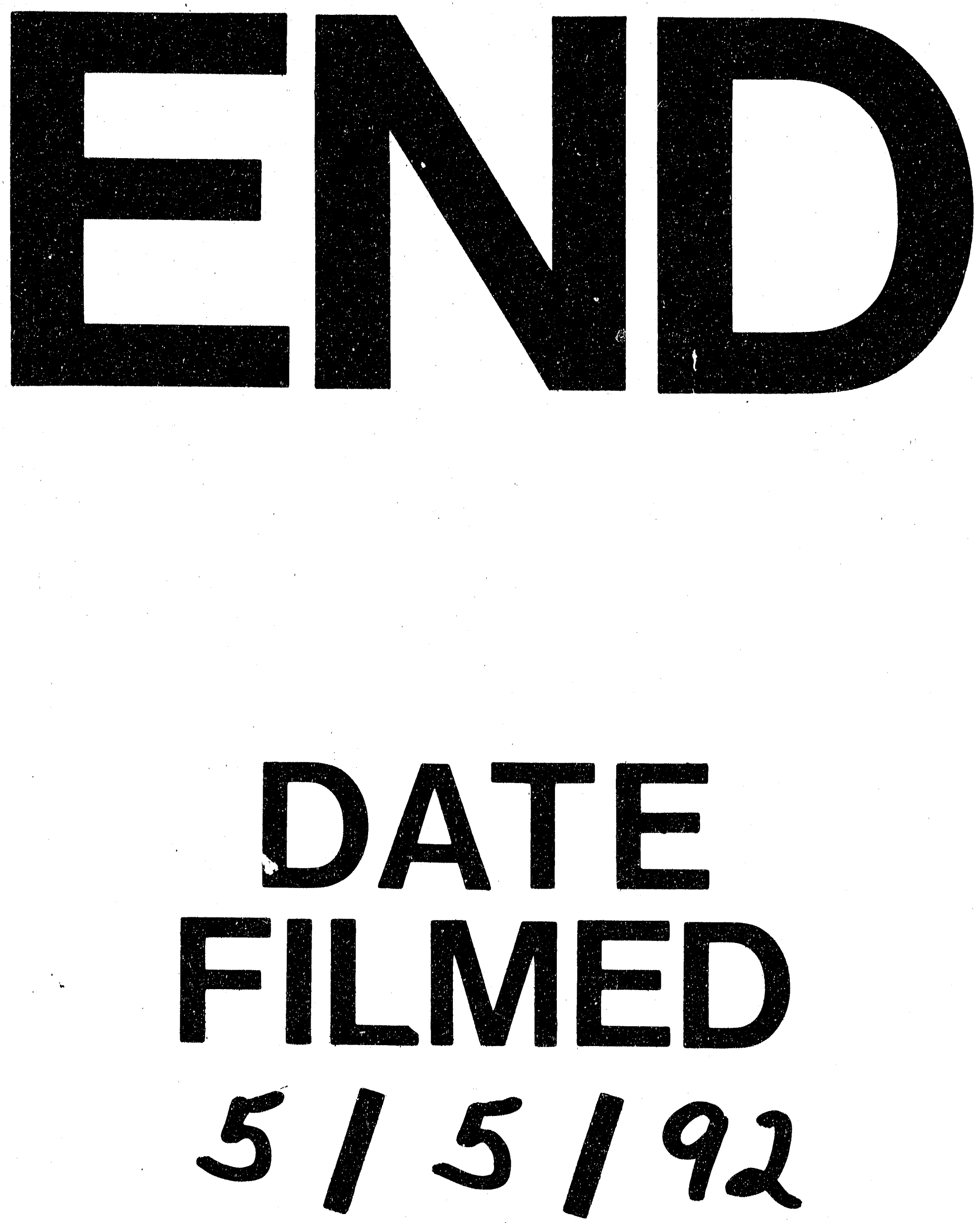
